\title{
Bioedusiana
}

http://jurnal.unsil.ac.id/index.php/bioed

DOI: https://doi.org/10.37058/bioed.v6i1.2968

Bioedusiana

\section{Analisis Kebutuhan untuk Pengembangan Bahan Ajar Berbentuk Komik Manga pada Materi Jaringan Hewan Kelas XI SMA}

\section{Analyzes of Necessity to Develop a Teaching Material in form of Manga Comic on Animal Tissue Concept}

\author{
Ummul Barokahhuda $^{1}$, Ramadhan Sumarmin $^{2 *}$, Helendra $^{3}$, Relsas Yogica ${ }^{4}$ \\ 1,2,3,4 Program Studi Pendidikan Biologi, Fakultas Matematika dan Ilmu Pengetahuan Alam, Universitas \\ Negeri Padang, Jl. Prof. Dr. Hamka Air Tawar, Padang, 25131
}

\begin{abstract}
Abstrak
Pemahaman peserta didik terhadap materi dan minat peserta didik terhadap pembelajaran dapat ditingkatkan dengan berbagai cara, salah satunya dengan menggunakan bahan ajar berupa komik. Peserta didik cenderung menyukai halhal yang sesuai dengan preferensi mereka, termasuk jenis bahan ajar yang digunakan dalam pembelajaran. Penelitian ini bertujuan untuk mengetahui preferensi peserta didik terhadap jenis komik yang akan dikembangkan sebagai bahan ajar pada materi jaringan hewan kelas XI SMA. Pendekatan deskriptif kuantitatif merupakan metode yang digunakan dalam penelitian ini dengan populasi berupa seluruh peserta didik kelas XI MIPA SMAN 1 Padang panjang. Sampel dipilih secara acak sebanyak $10 \%$ dari jumlah peserta didik pada masing-masing kelas dengan menggunakan teknik probability sampling-random sampling. Instrumen yang digunakan untuk mengumpulkan data penelitian adalah lembar wawancara oleh guru dan lembar angket analisis kebutuhan oleh peserta didik. Pada lembar angket analisis kebutuhan dilakukan analisis kurikulum, analisis bahan ajar dan analisis peserta didik. Hasil penelitian ini menunjukkan bahwa peserta didik membutuhkan alternatif bahan ajar lain berupa komik serta familier dan cenderung menyukai komik bergaya Jepang atau komik manga. Berdasarkan hasil penelitian ini, maka dibutuhkan pengembangan bahan ajar berbentuk komik manga pada materi jaringan hewan kelas XI SMA.
\end{abstract}

Kata kunci: Bahan Ajar; Komik; Materi Jaringan Hewan

\begin{abstract}
Students' understanding of the material and students' interest in learning can be improved in various ways, one of which is using teaching materials in the form of comics. Students tend to like things that match their preferences, including the teaching materials used in learning. This study aims to determine students' preferences for the types of comics developed as teaching materials for animal tissue material for 11th grade Senior High School. The descriptive quantitative approach is the method used in this study with all students of class 11th grade MIPA SMAN 1 Padang Panjang. The sample was randomly selected as much as 10\% of the students in each class using the probability sampling-random sampling technique. The instruments used to collect research data are interview sheets by teachers and needs analysis questionnaires by students. The needs analysis questionnaire, curriculum analysis, analysis of teaching materials and analysis of students are carried out. This study indicates that students need alternative teaching materials in the form of comics and are familiar and tend to like Japanese-style comics or manga comics. Based on the results of this study, it is necessary to develop teaching materials in the form of manga comics on animal tissue material for 11th grade SMA.
\end{abstract}

Keywords: Teaching Material; Comic; Animal Tissue Concept

\section{Article History}

Received: April 26 ${ }^{\text {th }}, 2021 ;$ Accepted: June 17 $7^{\text {th }}, 2021$; Published: June $30^{\text {th }}, 2021$

Corresponding Author*

Ramadhan Sumarmin, Program Studi Pendidikan Biologi, Fakultas Matematika dan Ilmu Pengetahuan Alam, Universitas Negeri Padang, E-mail: ramadhan_sum@fmipa.unp.ac.id 


\section{PENDAHULUAN}

Pembelajaran Biologi merupakan salah satu pembelajaran yang dilakukan pada jenjang pendidikan Sekolah Menengah Atas (SMA), yang mempelajari tentang seluk beluk makhluk hidup mulai dari tingkat molekular hingga tingkat ekosistem. Di antara materi yang diajarkan pada mata pelajaran Biologi di kelas XI SMA yaitu sel, bioproses sel, jaringan tumbuhan, jaringan hewan, sistem gerak, sistem sirkulasi, sistem pencernaan, sistem respirasi, sistem ekskresi, sistem koordinasi, sistem reproduksi, dan sistem imun.

Materi jaringan hewan merupakan materi yang dianggap sulit untuk dipahami oleh peserta didik. Hal ini didasarkan pada data observasi yang dilakukan di sekolah pada peserta didik kelas XI SMAN 1 Padang panjang terhadap kesukaran materi pelajaran Biologi pada semester ganjil. Hal ini senada dengan Triani et al. (2018), yang juga menyebutkan bahwa materi jaringan hewan merupakan materi yang dianggap sulit oleh peserta didik. Materi jaringan hewan memuat konsepkonsep yang bersifat abstrak, sehingga dibutuhkan bahan ajar yang sesuai untuk dapat menyampaikan konsep dari materi tersebut.

Bahan ajar merupakan sumber belajar yang digunakan oleh guru ataupun peserta didik pada proses pembelajaran. Penggunaan bahan ajar bertujuan agar materi yang diajarkan dapat disampaikan secara efektif kepada pengguna bahan ajar. Bahan ajar dapat dikemas dalam bentuk media cetak dan non cetak. Salah satu bahan ajar yang paling umum digunakan di sekolah adalah buku teks (Eroika et al., 2019; Mulyana \& Sumarmin, 2019; Sintia \& Sumarmin, 2019).

Berdasarkan data hasil observasi peserta didik kelas XI SMAN 1 Padang Panjang, menunjukkan bahwa penggunaan buku teks dianggap kurang menarik dan tidak mudah dimengerti oleh peserta didik. Hal ini senada dengan permasalahan pada penelitian Wahyuningsih (2012) bahwa penggunaan buku teks sebagai sumber belajar cenderung membosankan bagi peserta didik. Salah satu solusi yang dapat digunakan untuk memecahkan permasalahan tersebut adalah dengan menggunakan alternatif bahan ajar lainnya. Hal ini diperkuat dengan hasil wawancara yang dilakukan kepada salah satu guru Biologi SMAN 1 Padang panjang, diketahui bahwa komik merupakan media yang belum umum digunakan sebagai bahan ajar di sekolah.

Komik merupakan media bergambar dengan alur cerita yang umumnya digunakan sebagai media hiburan. Salah satu keunggulan komik yaitu dapat dinikmati oleh siapapun dan mudah dimengerti serta menarik minat pembaca (Kose, 2013; Widyastuti et al., 2017). Keunggulan tersebut kemudian dimanfaatkan sebagai media edukasi untuk menyampaikan materi pembelajaran seperti yang dilakukan oleh Kose (2013). Wulan et al. (2020) juga menyatakan bahwa penggunaan komik dalam pembelajaran dapat meningkatkan minat dan hasil belajar peserta didik. 
Berdasarkan hasil penelitian terkait penggunaan komik untuk pembelajaran yang telah dilakukan sebelumnya, dapat diduga bahwa penggunaan komik pada pembelajaran sangat membantu peserta didik, baik dalam peningkatan pemahaman terkait materi maupun peningkatan minat peserta didik terhadap pembelajaran. Namun jenis komik seperti apa yang cenderung peserta didik minati untuk digunakan dalam proses pembelajaran? Berdasarkan pertanyaan tersebut, maka harus dilakukan analisis kebutuhan untuk mengembangkan bahan ajar berbentuk komik yang sesuai dengan preferensi peserta didik pada materi jaringan hewan untuk kelas XI SMA. Tujuan dari penelitian ini adalah mengetahui preferensi peserta didik terhadap jenis komik yang akan dikembangkan sebagai bahan ajar pada materi jaringan hewan kelas XI SMA.

\section{METODE}

Metode yang digunakan pada penelitian ini adalah pendekatan deskriptif kuantitatif. Populasi pada penelitian ini adalah seluruh peserta didik kelas XI MIPA SMAN 1 Padang Panjang tahun ajaran 2020/2021 yang berjumlah 7 kelas dengan jumlah peserta didik 195 orang. Jumlah sampel diambil sebanyak $10 \%$ dari jumlah peserta didik per kelas, yang diharapkan agar sampel dapat menjadi gambaran besar dari populasi peserta didik kelas XI di SMAN 1 Padang panjang. Sampel dipilih dengan menggunakan teknik probability sampling-random sampling atau secara acak.

Data pada penelitian dikumpulkan dengan metode wawancara guru dan penyebaran angket kepada peserta didik. Instrumen penelitian yang digunakan adalah lembar wawancara semi-terstruktur dengan kisi-kisi sebagaimana yang tercantum pada Tabel 1 dan lembar angket analisis kebutuhan peserta didik sebagaimana yang tercantum pada Tabel 2. Data yang didapatkan kemudian dianalisis dengan menggunakan teknik analisis statistik deskriptif.

Tabel 1. Kisi-kisi wawancara

\begin{tabular}{cl}
\hline No. & \multicolumn{1}{c}{ Pertanyaan } \\
\hline 1. & Materi semester ganjil apa yang memiliki kendala untuk diajarkan kepada peserta didik? \\
2. & Mengapa? \\
3. & Materi semester ganjil apa yang sulit dipahami oleh peserta didik? \\
4. & $\begin{array}{l}\text { Bagaimana pendapat ibu mengenai penggunaan media belajar berbentuk komik sebagai } \\
\text { suplemen belajar peserta didik nantinya? }\end{array}$ \\
$5 . \quad \begin{array}{l}\text { Apakah peserta didik lebih dapat mengingat dan memahami materi yang disertai gambar saat } \\
\text { pembelajaran berlangsung? }\end{array}$ \\
\hline
\end{tabular}


Tabel 2. Angket analisis kebutuhan

\begin{tabular}{|c|c|}
\hline No. & Pertanyaan \\
\hline 1. & 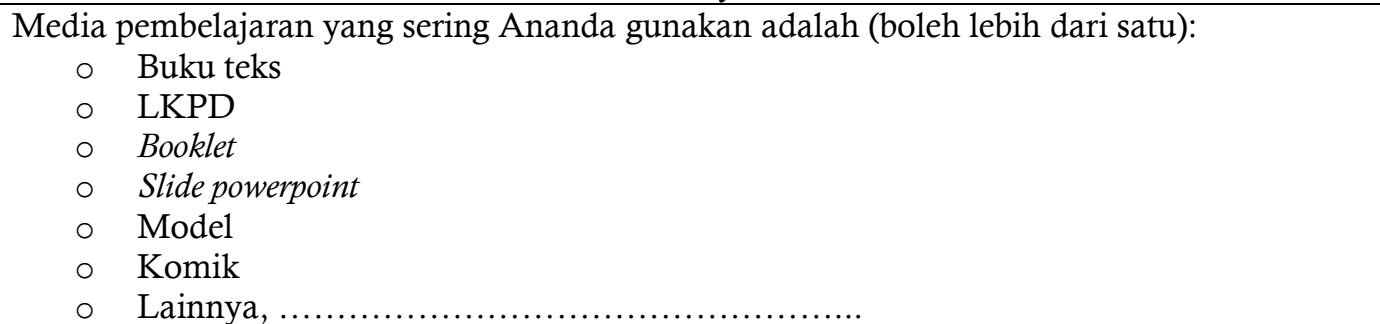 \\
\hline 2. & $\begin{array}{l}\text { Apakah Ananda menyukai cerita dalam bentuk narasi komik (seperti webtoon, manga/komik } \\
\text { jepang dan lainnya)? } \\
\circ \text { Sangat suka } \\
\circ \text { Suka } \\
\circ \text { Tidak suka } \\
\circ \text { Sangat tidak suka }\end{array}$ \\
\hline 3. & $\begin{array}{l}\text { Apakah Ananda pernah mendengar komik sebagai media pembelajaran? } \\
\circ \quad \text { Pernah } \\
\circ \quad \text { Tidak pernah }\end{array}$ \\
\hline 4. & $\begin{array}{l}\text { Bagaimanakah pendapat Ananda terhadap penggunaan komik sebagai media pembelajaran } \\
\text { biologi? } \\
\circ \text { Sangat tertarik } \\
\circ \text { Tertarik } \\
\circ \text { Tidak tertarik } \\
\circ \quad \text { Sangat tidak tertarik } \\
\end{array}$ \\
\hline 5. & $\begin{array}{ll}\text { Apakah media pembelajaran yang Ananda gunakan sudah menarik dan memotivasi? } \\
\circ \text { Sudah } \\
\circ \text { Cukup } \\
\circ \text { Belum } \\
\end{array}$ \\
\hline 6. & $\begin{array}{l}\text { Apakah media pembelajaran yang saat ini Ananda pakai lebih banyak menggunakan } \\
\text { penjelasan berupa paragraf-paragraf panjang? } \\
\circ \quad \text { Iya } \\
\circ \quad \text { Tidak }\end{array}$ \\
\hline 7. & $\begin{array}{l}\text { (Abaikan jika Ananda menjawab tidak pada poin no. 6) } \\
\text { Apakah penggunaan paragraf-paragraf panjang pada media tersebut sudah menarik dan } \\
\text { mudah dipahami? } \\
\quad \text { Sudah } \\
\circ \text { Cukup } \\
\circ \text { Belum }\end{array}$ \\
\hline 8. & $\begin{array}{cl}\text { Apakah Ananda membutuhkan media pembelajaran lain sebagai alternatif belajar? } \\
\circ \text { Sangat butuh } \\
\circ \text { Butuh } \\
\circ & \text { Tidak butuh } \\
\circ & \text { Sangat tidak butuh }\end{array}$ \\
\hline 9. & 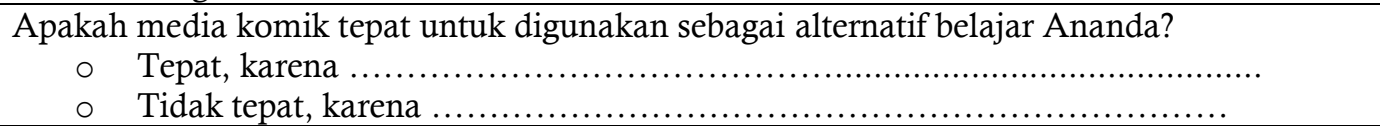 \\
\hline 10. & 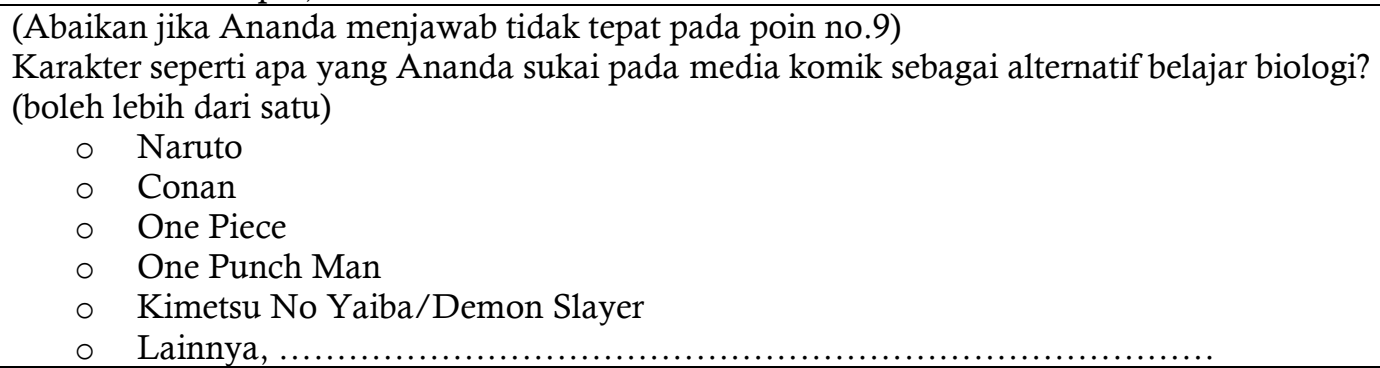 \\
\hline
\end{tabular}

11. (Abaikan jika Ananda menjawab tidak tepat pada poin no.9) 


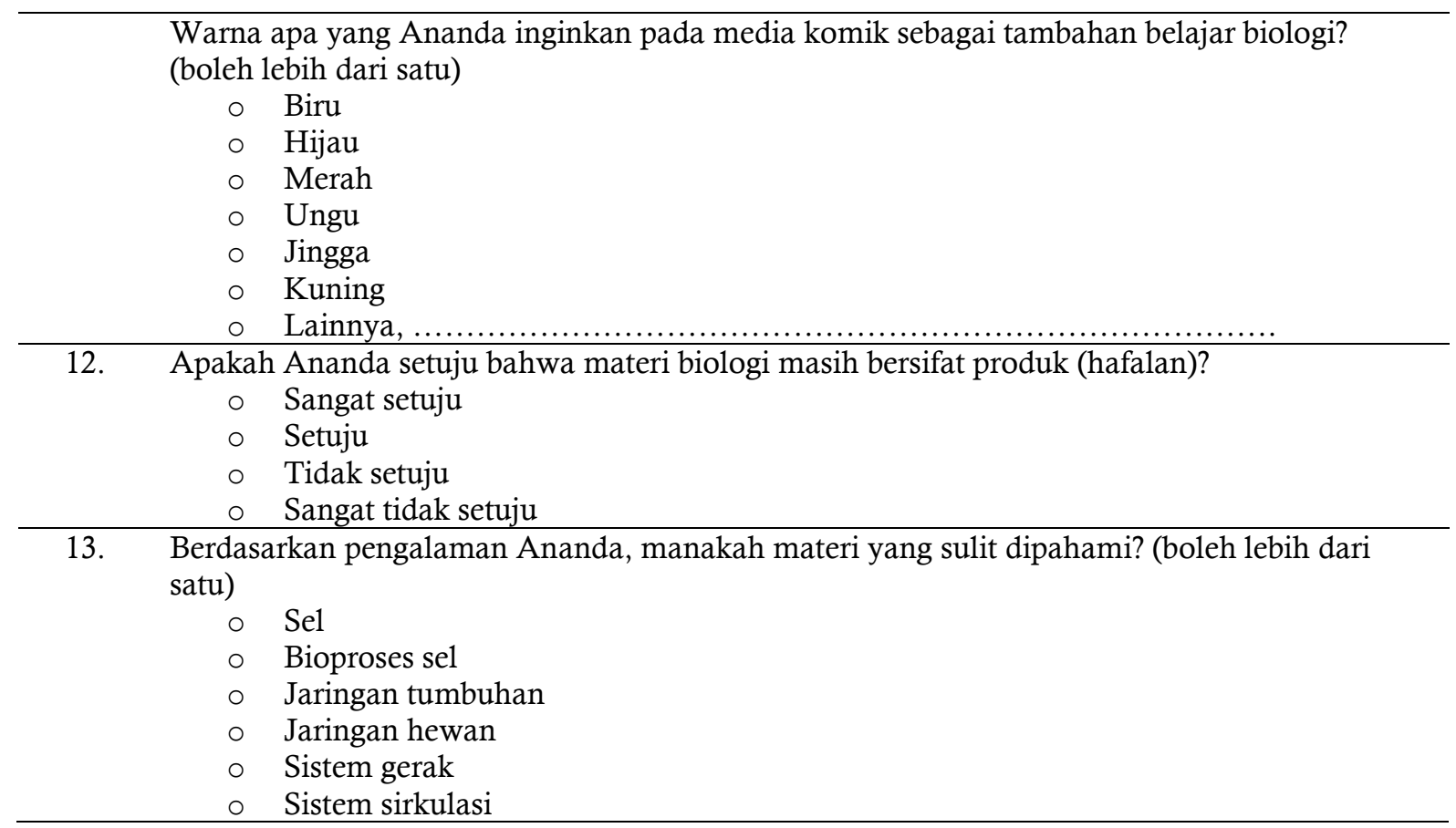

Berikut langkah-langkah yang dilakukan pada penelitian analisis kebutuhan untuk mengembangkan bahan ajar berbentuk komik manga pada materi jaringan hewan pada kelas XI SMA.

1. Analisis Kurikulum

Analisis kurikulum dilakukan untuk mengetahui Indikator Pencapaian Kompetensi (IPK) dan tujuan pembelajaran yang harus dicapai oleh peserta didik. Analisis ini dilakukan dengan melihat materi tersulit bagi peserta didik beserta nilai rata-rata ulangan harian terendah pada materi biologi semester ganjil. Setelah mendapatkan materi biologi pada semester ganjil yang dianggap sulit bagi peserta didik, dilakukan analisis Kompetensi Dasar (KD) pada materi terkait yang sesuai dengan kurikulum 2013. Perumusan Indikator Pencapaian Kompetensi (IPK) dan tujuan pembelajaran dilakukan setelah analisis Kompetensi Dasar (KD).

2. Analisis Bahan Ajar

Analisis bahan ajar dilakukan untuk mengetahui bahan ajar yang umum dan tidak umum digunakan pada proses pembelajaran di sekolah. Analisis ini juga dilakukan untuk mengetahui apakah bahan ajar yang umum digunakan pada pembelajaran mudah dipahami dan menarik bagi peserta didik.

\section{Analisis Peserta Didik}

Analisis peserta didik dilakukan untuk mengetahui preferensi peserta didik terhadap bahan ajar yang akan dikembangkan. Preferensi yang dimaksud yaitu jenis bahan ajar dan tipe yang cenderung diminati oleh peserta didik. 
Barokahhuda et al., - Bioedusiana, 6 (1) Juni 2021 


\section{HASIL DAN PEMBAHASAN}

\section{Hasil}

Sebelum dilakukan pengembangan pada materi Biologi, terlebih dahulu dilakukan pendataan dan pemetaan materi Biologi berdasarkan tingkat kesulitannya menurut peserta didik. Tabel 3 berikut ini merupakan materi Biologi berdasarkan tingkat kesulitannya menurut peserta didik kelas XI MIPA SMAN 1 Padang Panjang.

Tabel 3. Persentase kesulitan materi biologi pada semester ganjil

\begin{tabular}{clc}
\hline No. & \multicolumn{1}{c}{ Materi } & Persentase Kesulitan \\
\hline 1. & Sel & $10 \%$ \\
2. & Bioproses sel & $23 \%$ \\
3. & Jaringan tumbuhan & $23 \%$ \\
4. & Jaringan hewan & $25 \%$ \\
5. & Sistem gerak & $7 \%$ \\
6. & Sistem sirkulasi & $11 \%$ \\
\hline
\end{tabular}

Berdasarkan pada Tabel 3 tersebut menunjukkan persentase kesulitan materi biologi pada semester ganjil menurut peserta didik kelas XI SMAN 1 Padang Panjang. Materi jaringan hewan merupakan materi tersulit dengan nilai persentase tertinggi sebesar 25\%. Materi yang dianggap sulit oleh peserta didik selanjutnya adalah materi bioproses sel dan jaringan tumbuhan dengan nilai persentase masing-masing sebesar 23\%. Hasil wawancara guru menunjukkan bahwa materi bioproses sel merupakan materi yang termasuk sulit untuk diajarkan kepada peserta didik karena bersifat abstrak. Dalam rangka mempersempit opsi dari materi yang relatif sukar dipahami oleh peserta didik tersebut, maka dilakukan peninjauan nilai rata-rata ulangan harian pada masingmasing Kompetensi Dasar seperti pada Tabel 4 berikut.

Tabel 4. Nilai rata-rata ulangan harian per kelas pada masing-masing kompetensi dasar

\begin{tabular}{ccccccc}
\hline Kelas & KD 3.1 & KD 3.2 & KD 3.3 & KD 3.4 & KD 3.5 & KD 3.6 \\
\hline XI MIPA 1 & 92,2 & 86,7 & 73 & 65 & 81,6 & 88 \\
XI MIPA 2 & 99,3 & 85,4 & 88,2 & 82,5 & 93,1 & 89,5 \\
XI MIPA 3 & 95,9 & 87,1 & 69,6 & 80 & 82,3 & 89,1 \\
XI MIPA 4 & 96,9 & 87,9 & 69,8 & 53,7 & 79,4 & 83,2 \\
XI MIPA 5 & 90,9 & 86,1 & 71,8 & 47,6 & 85,9 & 88 \\
XI MIPA 6 & 96,5 & 88,3 & 68,3 & 57,6 & 73,9 & 89 \\
\hline Rata-rata & 95,2 & 86,9 & 73,4 & 64,4 & 82,7 & 87,8 \\
\hline
\end{tabular}

Data pada Tabel 4 tersebut menunjukkan nilai rata-rata ulangan harian masing-masing kelas pada Kompetensi Dasar 3.1-3.6. Berdasarkan data tersebut, diperoleh nilai rata-rata terendah yaitu pada Kompetensi Dasar 3.4 dengan angka 64,4. Kompetensi dasar 3.4 pada kelas XI SMA merupakan kompetensi yang mempelajari tentang materi jaringan hewan. Selanjutnya, 
dilakukan juga analisis mengenai berbagai jenis bahan ajar yang digunakan di kelas XI MIPA SMAN 1 Padang Panjang, dengan hasil seperti yang ditunjukkan pada Gambar 1 berikut.

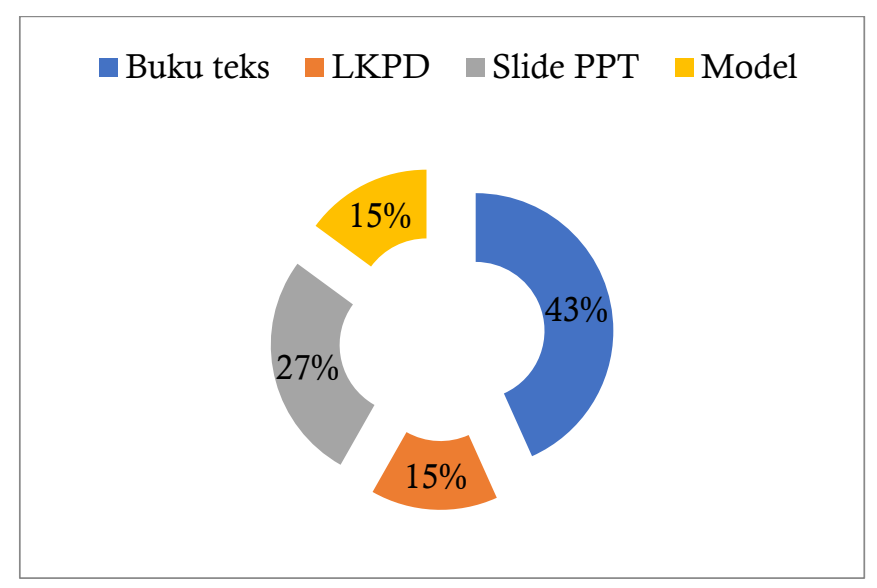

Gambar 1. Grafik persentase bahan ajar yang umum digunakan di sekolah

Grafik pada Gambar 1 tersebut menunjukkan persentase bahan ajar yang umum digunakan di sekolah. Buku teks merupakan bahan ajar yang paling umum digunakan di sekolah dengan angka persentase tertinggi sebesar 43\%. Bahan ajar selanjutnya yang juga umum digunakan di sekolah yaitu slide powerpoint dengan angka persentase sebesar 27\% serta LKPD dan model dengan angka persentase masing-masing sebesar 15\%. Berdasarkan wawancara salah satu guru biologi, diperoleh fakta bahwa bahan ajar berbentuk komik sangat tidak umum digunakan dalam proses pembelajaran di sekolah.

Kemudian, setelah diketahui bahwa buku teks Biologi merupakan bahan ajar yang paling banyak digunakan, selanjutnya dilakukan analisis mengenai aspek ketertarikan dan pemahaman peserta didik terhadap buku teks tersebut, sebagaimana yang tercantum pada grafik Gambar 2 berikut.

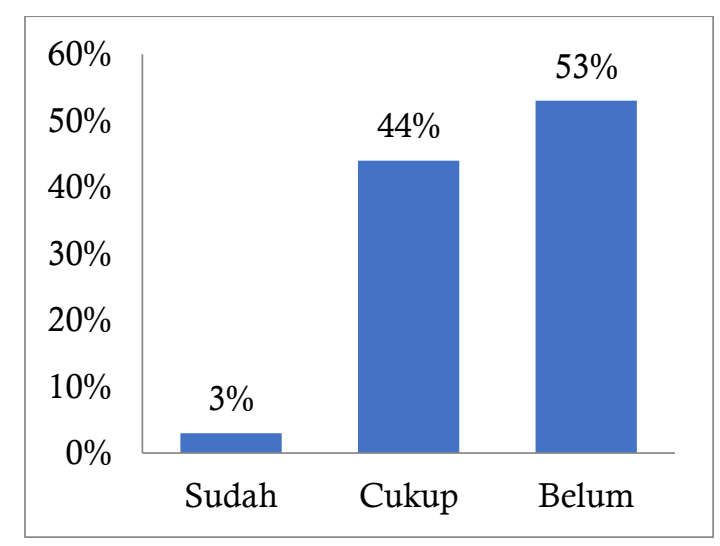

Gambar 2. Grafik persentase kemudahan dan daya tarik buku teks biologi

Grafik pada Gambar 2 tersebut menunjukkan persentase kemudahan dan daya tarik buku teks biologi yang digunakan di sekolah. Berdasarkan data tersebut, 53\% peserta didik menyatakan 
bahwa buku teks belum menarik dan belum mudah dipahami. Sebesar $44 \%$ peserta didik menyatakan bahwa buku teks cukup menarik dan cukup mudah dipahami serta sebesar 3\% peserta didik menyatakan bahwa buku teks sudah menarik dan sudah mudah dipahami.

Setelah diketahui bahwa sebagian besar persentase peserta didik yang menyatakan bahwa buku teks masih sulit dipahami dan kurang menarik perhatian, maka tahapan berikutnya adalah mengumpulkan data mengenai kebutuhan peserta didik terhadap bahan ajar alternatif selain buku teks. Hasil dari angket tersebut disajikan pada Tabel 5 berikut.

Tabel 5. Persentase kebutuhan peserta didik terhadap media bahan ajar lain

\begin{tabular}{lc}
\hline Kriteria & Persentase \\
\hline Sangat butuh & $22 \%$ \\
Butuh & $70 \%$ \\
Tidak Butuh & $5 \%$ \\
Sangat Tidak Butuh & $3 \%$ \\
\hline
\end{tabular}

Berdasarkan data pada Tabel 5 tersebut, menunjukkan persentase kebutuhan peserta didik terhadap media bahan ajar lain selain buku teks. Sebanyak 70\% peserta didik menyatakan butuh terhadap bahan ajar lain dan sebanyak $22 \%$ menyatakan sangat butuh terhadap bahan ajar lain. Berbekal data ini, maka diperlukan sebuah bahan ajar alternatif pengganti buku teks yang telah ada sebelumnya.

Berikutnya, dilakukan analisis minat peserta didik terhadap bahan ajar alternatif yang ditawarkan, yaitu berupa komik. Berdasarkan kuesioner yang telah disebarkan, didapatkan data sebagaimana yang ditampilkan pada grafik Gambar 3, Gambar 4, dan Tabel 6 berikut.

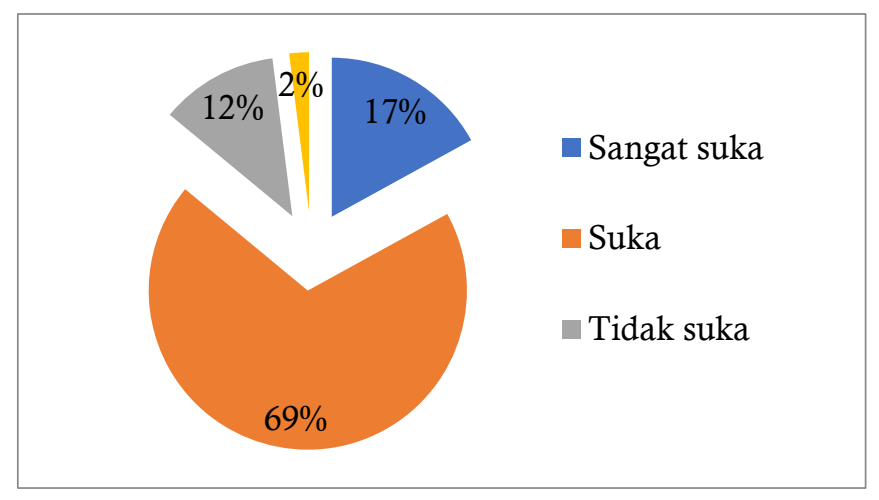

Gambar 3. Grafik minat baca peserta didik terhadap komik

Grafik pada Gambar 3 tersebut menunjukkan minat baca peserta didik terhadap komik. Sebanyak $86 \%$ peserta didik menyukai kegiatan membaca komik di mana $17 \%$ menyatakan sangat suka dan $69 \%$ menyatakan suka. 
Tabel 6. Persentase ketertarikan peserta didik terhadap penggunaan komik sebagai bahan ajar

\begin{tabular}{lc}
\hline Kriteria & Persentase \\
\hline Sangat tertarik & $18 \%$ \\
Tertarik & $80 \%$ \\
Tidak Tertarik & $0 \%$ \\
Sangat Tidak Tertarik & $2 \%$ \\
\hline
\end{tabular}

Data pada Tabel 6 tersebut menunjukkan persentase ketertarikan peserta didik terhadap penggunaan komik sebagai alternatif bahan ajar. Sebanyak $80 \%$ peserta didik menyatakan tertarik dan $18 \%$ menyatakan sangat tertarik.

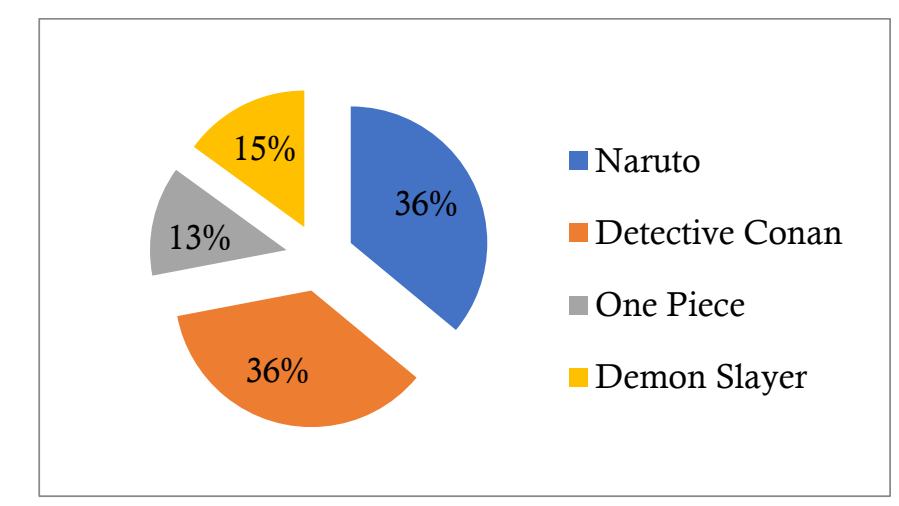

Gambar 4. Grafik preferensi peserta didik terhadap jenis komik

Grafik pada Gambar 4 menunjukkan persentase preferensi peserta didik terhadap jenis komik. Berdasarkan data tersebut diperoleh masing-masing 36\% peserta didik menyukai komik Naruto dan Detective Conan, 15\% menyukai komik Demon Slayer dan 13\% menyukai komik One Piece. Dilihat dari jenis komik yang disukai oleh peserta didik, diketahui bahwa komik-komik tersebut termasuk ke dalam jenis komik Jepang atau disebut juga dengan manga.

\section{Pembahasan}

Berdasarkan data yang didapatkan dari analisis kurikulum, diperoleh materi jaringan hewan pada Kompetensi Dasar 3.4 sebagai materi yang sulit dipahami oleh peserta didik. Materi jaringan hewan dianggap materi yang sulit untuk dipahami karena bersifat abstrak dan kompleks (Triani et al., 2018). Hal tersebut juga dapat dilihat dari nilai rata-rata ulangan harian peserta didik kelas XI MIPA 1-6 SMAN 1 Padang panjang pada masing-masing Kompetensi Dasar di semester ganjil. Data yang diperoleh menunjukkan bahwa Kompetensi Dasar 3.4 menganalisis keterkaitan antara struktur jaringan, letak dan fungsi organ pada hewan merupakan materi yang memiliki nilai rata-rata ulangan harian terendah. 
Materi jaringan hewan merupakan materi yang terdapat pada kompetensi dasar 3.4 kelas XI SMA dengan Indikator Pencapaian Kompetensi sebagai berikut:

3.4.1. peserta didik mampu menyebutkan jaringan utama pada hewan;

3.4.2. peserta didik mampu menguraikan jaringan utama pada hewan;

3.4.3. peserta didik mampu menganalisis keterkaitan struktur penyusun jaringan dengan fungsinya pada organ; dan

3.4.4. peserta didik mampu mengidentifikasi jenis jaringan hewan pada organ berdasarkan fungsinya.

Sedangkan, tujuan pembelajaran berkaitan dengan indikator pencapaian dari Kompetensi Dasar. Tujuan pembelajaran dari materi jaringan hewan untuk kelas XI SMA adalah sebagai berikut:

3.4.1. dapat menyebutkan masing-masing jaringan hewan;

3.4.2. dapat menjelaskan perbedaan masing-masing jaringan hewan;

3.4.3. dapat mengaitkan struktur penyusun jaringan dengan fungsinya pada organ; dan

3.4.4. dapat menentukan jenis jaringan pada organ berdasarkan fungsinya.

Hasil analisis bahan ajar menunjukkan bahwa buku teks merupakan sumber belajar utama yang digunakan pada pembelajaran di sekolah. Berdasarkan data yang diperoleh, 53\% peserta didik menyatakan bahwa buku teks kurang menarik dan belum mudah dipahami. Penggunaan hanya buku teks dalam pembelajaran konvensional juga berdampak terhadap motivasi peserta didik. Hal tersebut menyebabkan peserta didik tidak termotivasi untuk berpartisipasi secara aktif pada saat proses pembelajaran berlangsung (Puspitasari \& Panggabean, 2016). Hosler \& Boomer (2011) menyebutkan bahwa buku teks tidak selalu dapat menyampaikan daya tarik, suka cita, dan kegunaan dari ilmu pengetahuan, terutama bagi peserta didik yang kurang meminati materi yang disampaikan pada buku teks.

Permasalahan tersebut dapat diatasi dengan menggunakan bahan ajar tambahan yang menarik bagi peserta didik. Berdasarkan data yang diperoleh dari penelitian ini, sebanyak 92\% peserta didik menyatakan butuh terhadap alternatif bahan ajar lain. Salah satu media yang dapat dimanfaatkan sebagai bahan ajar tambahan yang menarik yaitu komik (Jee \& Anggoro, 2012).

Komik merupakan media yang disukai oleh sebagian besar peserta didik (Swandi et al., 2020). Hasil analisis peserta didik menunjukkan bahwa sebesar $86 \%$ peserta didik menikmati kegiatan membaca komik dan sebesar 98\% merasa tertarik dengan penggunaan komik sebagai bahan ajar. Data tersebut dapat digunakan sebagai dasar dalam rangka menciptakan dan menggunakan komik sebagai salah satu bahan ajar tambahan untuk peserta didik. Hal ini didukung oleh pernyataan Jee \& Anggoro (2012) bahwa salah satu cara terbaik untuk memaparkan ilmu pengetahuan kepada peserta didik adalah dengan menggunakan media yang 
sudah umum digunakan dan dinikmati oleh peserta didik itu sendiri, contohnya komik. Zagkotas (2019) menyebutkan bahwa komik memberi dampak yang luar biasa bagi peserta didik. Hal tersebut juga menarik perhatian pendidik untuk menciptakan bahan ajar tambahan dalam bentuk komik karena penggunaan bentuk yang sudah familier dan populer di kalangan peserta didik serta dapat membuat pembelajaran menjadi lebih menarik.

Adapun dampak penggunaan komik sudah diteliti oleh banyak pihak, diantaranya yaitu penelitian yang dilakukan oleh Hosler \& Boomer (2011). Penelitian tersebut menunjukkan bahwa penggunaan komik menghasilkan peningkatan signifikan terhadap pemahaman materi bagi peserta didik jurusan non-IPA dan peserta didik jurusan IPA yang memiliki nilai rendah pada materi biologi. Hal tersebut menunjukkan bahwa komik memiliki peran dalam menarik minat dan membentuk pemahaman peserta didik terhadap materi. Komik juga dapat digunakan untuk menyampaikan informasi saintifik kepada masyarakat dengan cara yang menyenangkan serta mudah untuk dimengerti dan diingat (Negrete, 2013). Hasil penelitian dari Sangur et al. (2021) menunjukkan bahwa penggunaan komik dalam pembelajaran dapat meningkatkan kemampuan peserta didik dalam berpikir kritis dan memecahkan masalah serta meningkatkan motivasi belajar peserta didik. Selain memotivasi peserta didik untuk belajar, komik juga memiliki kemampuan untuk mengurangi kebosanan peserta didik (Karap, 2017) pada saat pembelajaran berlangsung. Respon peserta didik terhadap penggunaan komik dalam proses pembelajaran yang dilakukan oleh Phoon et al. (2020) menunjukkan bahwa peserta didik menikmati kegiatan pembelajaran dengan menggunakan komik serta tertarik untuk menggunakan komik pada pembelajaran selanjutnya.

Hasil wawancara dari salah seorang guru biologi di SMAN 1 Padang Panjang menunjukkan fakta bahwa penggunaan komik sebagai bahan ajar belum umum dan tidak pernah dilakukan di sekolah. Situasi tersebut sesuai untuk dilakukannya penelitian dengan menggunakan komik sebagai bahan ajar karena akan dapat menarik minat peserta didik. Hal tersebut dikarenakan selain dapat memberikan pengalaman baru bagi peserta didik dalam proses pembelajaran, komik juga memiliki potensi untuk menyampaikan materi yang bersifat kompleks serta dapat meningkatkan capaian kompetensi (Roswati et al., 2019; Sousanis, 2017).

Komik terdiri dari beberapa jenis, di antaranya yang paling umum yaitu manga, manhua, manhwa dan komik barat. Pengelompokan jenis komik ini didasarkan dari asal komik tersebut diciptakan. Manga merupakan komik yang berasal dari Jepang, contohnya komik Naruto, Detective Conan dan One Piece. Manhua merupakan komik yang berasal dari Cina, contohnya Star Martial God. Manhwa merupakan komik yang berasal dari Korea, contohnya yaitu Tower of God, Noblesse dan Orange Marmalade (Amelia, n.d.). Sedangkan komik Barat berasal dari Amerika, contohnya komik Marvel. 
Data preferensi peserta didik terhadap komik menunjukkan bahwa jenis komik yang paling diminati oleh peserta didik adalah komik Jepang atau manga. Seperti yang dapat dilihat pada Grafik 4, data yang diperoleh merupakan komik-komik yang berasal dari Jepang dan umumnya disebut dengan komik manga. Peserta didik yang merupakan generasi muda mungkin lebih familier dengan komik manga yang berasal dari Jepang dibandingkan komik lain seperti komik Marvel dari Barat karena karakteristiknya yang unik (Phoon et al., 2020).

Perbedaan mencolok dari komik manga dan komik barat adalah penggunaan gambar dan bahasa. Komik manga lebih banyak menggunakan gambar dan sedikit kalimat daripada komik barat yang berasal dari Amerika. Penekanan cerita terhadap gambar dan penggunaan onomatopoeia sebagai cara menyampaikan cerita merupakan keunggulan dari komik manga jika dibandingkan dengan komik barat (Kincaid, n.d.).

Saat ini komik manga diakui sebagai fenomena populer yang berpengaruh secara global. Karakteristiknya yang unik menjadikannya berbeda dari jenis komik lainnya. Penggunaan simbol dan balon teks yang menerangkan situasi atau mood karakter saat berdialog merupakan salah satu ciri khas manga. Simbol yang umum digunakan pada manga yaitu onomatopoeia atau simbol yang menjelaskan suara dan mimetics atau simbol yang menjelaskan bentuk merupakan deskriptor psikologis dan suasana yang mudah untuk dipahami oleh pembaca (Natsume, 2020).

Komik manga sebagai media pembelajaran sudah sejak lama digunakan di Jepang untuk membantu peserta didik memperoleh pengetahuan sekaligus membuat kegiatan belajar terasa menyenangkan. Popularitas komik manga dalam dunia pendidikan juga sudah dibuktikan di luar Jepang. Contohnya yaitu penggunaan buku teks berbasis manga pada pembelajaran oleh guru bahasa Jepang untuk membantu meningkatkan motivasi belajar peserta didik (Natsume, 2020). Penggunaan komik manga untuk penyampaian materi ajar di sekolah-sekolah perlu dikaji lebih lanjut sebagai suplemen bahan ajar.

Komik dapat menyampaikan pesan pembelajaran dari materi pelajaran yang bersifat kompleks. Keunggulan ini dapat digunakan sebagai media yang tepat untuk menyampaikan materi jaringan hewan kelas XI SMA. Jenis komik manga yang lebih familier dan populer di kalangan peserta didik akan lebih menarik minat peserta didik untuk belajar. Dengan mengembangkan bahan ajar berbentuk komik manga, peserta didik akan merasa lebih tertarik karena sesuai dengan preferensi peserta didik terhadap komik pada umumnya.

\section{SIMPULAN}

Berdasarkan hasil penelitian maka diperoleh kesimpulan bahwa penelitian pengembangan komik manga pada materi jaringan hewan untuk kelas XI SMA perlu dilakukan. Pembelajaran dengan menggunakan komik manga dapat lebih menarik minat peserta didik sehingga dapat 
meningkatkan minat belajar dan pemahaman peserta didik terhadap materi jaringan hewan yang disampaikan melalui komik manga.

Saran bagi peneliti selanjutnya yang akan melakukan penelitian terkait komik manga adalah mengumpulkan informasi mengenai genre komik manga yang diminati oleh peserta didik. Hal tersebut dilakukan untuk mengantisipasi sense-style dari genre komik yang umum disukai oleh peserta didik sehingga dapat menyesuaikannya terhadap genre komik yang akan diciptakan. Dengan begitu maka komik manga yang diciptakan akan lebih mudah diterima oleh peserta didik.

\section{REFERENSI}

Amelia, D. E. (n.d.). Mengenal Perbedaan Manga, Manhwa, Manhua dalam Dunia Perkomikan _ Halaman 3. https://www.viva.co.id/siaran-pers/1224085-mengenal-perbedaan-mangamanhwa-manhua-dalam-dunia-perkomikan?page=3\&utm_medium=selanjutnya-3

Eroika, V., Sumarmin, R., Helendra, H., \& Yuniarti, E. (2019). The Needs Analysis of The Develop of Biology Module Based On Scientific Approach for Senior High School Grade XI $\begin{array}{lllll}\text { Students. } & \text { Atrium } & \text { Pendidikan } & \text { Biologi, } & \text { 4(2), }\end{array}$ http://ejournal.unp.ac.id/students/index.php/pbio/article/view/5828/3048

Hosler, J., \& Boomer, K. B. (2011). Are Comic Books an Effective Way to Engage Nonmajors in Learning and Appreciating Science? CBE Life Sciences Education, 10(3), 309-317. https://doi.org/10.1187/cbe.10-07-0090

Jee, B., \& Anggoro, F. K. (2012). Cognitive Impacts of Science Comics. Journal of Cognitive Education and Psychology, 11(2). http://dx.doi.org/10.1891/1945-8959.11.2.196

Karap, Z. (2017). The Possible Benefits of Using Comic Books in Foreign Language Education: A Classroom Study. Képzés És Gyakorlat, 15(1-2), 243-260. https://doi.org/10.17165/tp.2017.1-2.14

Kincaid, C. (n.d.). Manga and Your Mind: Manga, Autism, and the Benefits of Reading - Japan Powered. https://www.japanpowered.com/anime-articles/manga-autism-reading-benefits

Kose, O. E. (2013). Effects of Cartoons on Students' Achievement and Attitudes in Biology Teaching. Kastamonu Education Journal, 21(3), 931-944. http://dx.doi.org/10.30998/formatif.v10i2.6257

Mulyana, A., \& Sumarmin, R. (2019). Needs Analysis to Development of Biology Module Based on Problem Solving at Topics of Respiratory and Excretory System to Student of Senior High School Grade XI. Journal of Physics: Conference Series, 1317(1). https://doi.org/10.1088/17426596/1317/1/012196

Natsume, F. (2020). The Grammar of Manga: Manga's Inherent Hyogen Stylistics. In masami Toku \& hiromi tsuchiya Dollase (Eds.), MANGA! Visual Pop-Culture in ARTS Education (pp. 
1-10). InSEA Publications. https://doi.org/10.24981/2020-3

Negrete, A. (2013). Constructing a Comic to Communicate Scientific Information about

Sustainable Development and Natural Resources in Mexico. Procedia - Social and Behavioral Sciences, 103, 200-209. https://doi.org/10.1016/j.sbspro.2013.10.327

Phoon, H., Roslan, R., Shahrill, M., \& Said, H. M. (2020). The Role of Comics in Elementary School Science Education. Formatif: Jurnal Ilmiah Pendidikan MIPA, 10(148), 67-76. http://dx.doi.org/10.30998/formatif.v10i2.6257

Puspitasari, R. A., \& Panggabean, C. I. T. (2016). The Use of Comic As Media in Teaching Speaking of Narrative Text for the Eighth Graders of Junior High School. Jurnal Teladan: Jurnal Ilmu Pendidikan Dan Pembelajaran, 1(2), 73-80. http://journal.unirow.ac.id/index.php/teladan/article/view/9

Roswati, N., Rustaman, N. Y., \& Nugraha, I. (2019). The Development of Science Comic in Human Digestive System Topic for Junior High School Students. Journal of Science Learning, 3(1), 12-18. https://doi.org/10.17509/jsl.v3i1.18120

Sangur, K., \& Makatita, A. (2021). The Effectiveness of Digital Comics in Improving Industrial Revolution Skills and Student Motivation. Edu Sciences $J$, 2(1), 55-61. https://ojs3.unpatti.ac.id/index.php/edusciences/article/view/3289

Sintia, M., \& Sumarmin, R. (2019). Need Analysis to Development Guide-Module Based on Inquiry in Respiratory and Excretion Topics for Students of Class XI Senior High School. Journal of Physics: Conference Series, 1317(1). https://doi.org/10.1088/17426596/1317/1/012188

Sousanis, N. (2017). Science Meets Comics. In R. Leinfelder, A. Hamann, J. Kirstein, \& M. Schleuniz (Eds.), Proceedings of the Symposium on Communicating and Designing the Future of Food in the Anthropocene. Christian A. Bachmann Verlag. https://www.researchgate.net/publication/315703564_Science_meets_Comics_Proceeding s_of_the_Symposium_on_Communicating_and_Designing_the_Future_of_Food_in_the_A nthropocene

Swandi, I. W., Wibawa, A. P., Pradana, G. Y. K., \& Suarkad, I. N. (2020). The Digital Comic Tantri Kamandaka: A discovery for National Character Education. International Journal of Innovation, Creativity and Change, 13(3), 718-732. https://www.ijicc.net/images/vol_13/Iss_3/13396_Swandi_2020_E_R.pdf

Triani, L., Wahyuni, S., Purwanti, E., Hudha, A. M., Fatmawati, D., \& Husamah, H. (2018). Pembelajaran I-CARE Berbantuan Praktikum: Peningkatan Problem- Solving Skills dan Hasil Belajar Siswa pada Materi Jaringan Hewan. Jurnal Inovasi Pendidikan IPA, 4(2), 158168. https://journal.uny.ac.id/index.php/jipi/article/view/21826/11599 
Wahyuningsih, A. N. (2012). Pengembangan Media Komik Bergambar Materi Sistem Saraf untuk Pembelajaran yang Menggunakan Strategi Pq4R. Journal of Innovative Science Education, 1(1), 19-27. http://journal.unnes.ac.id/sju/index.php/jise/article/view/40/29

Widyastuti, P. D., Mardiyana, M., \& Saputro, D. R. S. (2017). An Instructional Media using Comics on the Systems of Linear Equation. Journal of Physics: Conference Series, 895(1). https://doi.org/10.1088/1742-6596/895/1/012039

Wulan, I. S., Suprapto, P. K., \& Kamil, P. M. (2020). Belajar Virus dengan Komik: Pengaruhnya terhadap Motivasi dan Hasil Belajar (Studi Eksperimen di Kelas X MAN Tasikmalaya Tahun Ajaran 2019/2020). Bioedusiana: Jurnal Pendidikan Biologi, 5(Vol 5 Nomor 2 Desember 2020), 70-83. https://doi.org/10.37058/bioed.v5i2.2005

Zagkotas, V. (2019). Are Comic Books Appropriate for Teaching History? Three Suggestions for Greek Primary Education. Education 3-13, 47(3), 358-365. https://doi.org/10.1080/03004279.2018.1452955 